\title{
Enterprise Architecture Planning E-Marketplace UMKM Kota Palembang
}

\author{
Abiyasa Eka Saputra'), Darius Antoni ${ }^{2)}$, dan Muhamad Akbar ${ }^{3)}$ \\ e-mail: abiyasa.eka@gmail.com ${ }^{1)}$, darius.antoni@binadarma.ac.id ${ }^{2)}$, muhamad.akbar@binadarma.ac.id ${ }^{3)}$ \\ ${ }^{1,2,3)}$ Program Pascasarjana Universitas Bina Darma
}

\begin{abstract}
Abstrak
Indonesia memerlukan pertumbuhan ekonomi paling tidak 7\% pertahun agar target pada tahun 2025 yaitu menjadi negara berpendapatan menengah bisa dicapai yang mana saat ini baru terealisasi sebesar 5\%. Salah satu cara untuk meningkatkan pertumbuhan tersebut adalah dengan mendorong UMKM untuk meningkatkan keterlibatannya secara digital. Salah satu caranya adalah dengan mendorong UMKM untuk menggunakan e-marketplace. E-marketplace akan memperluas pasar UMKM sehingga bisa meningkatkan pertumbuhan ekonomi. Agar penerapan suatu teknologi informasi bisa maksimal, diperlukan suatu kerangka pedoman pengembangan teknologi informasi tersebut agar teknologi informasi tersebut bisa sesuai dengan tujuannya. Oleh karena itu diperlukan suatu metode yang baik. Enterprise Architecture Planning (EAP) merupakan suatu metode untuk membuat kerangka acuan suatu arsitektur informasi untuk mendukung aktivitas bisnis dengan berorientasi pada kebutuhan bisnis demi mencapai misi suatu organisasi. Penelitian ini memberikan hasil berupa model proses bisnis UMKM Kota Palembang, arsitekur data, aplikasi dan teknologi serta rencana implementasinya sebagai pedoman atau cetak biru untuk perancangan e-marketplace UMKM Kota Palembang.
\end{abstract}

Keywords: EAP, enterprise architecture planning, blueprint, UMKM Kota Palembang, e-marketplace

\section{Pendahuluan}

Pemerintah Indonesia mempunyai target pada rancangan kebijakan Masterplan Percepatan dan Perluasan Pembangunan Ekonomi Indonesia (MP3EI) untuk mengubah Indonesia menjadi negara berpendapatan menengah pada tahun 2025. Untuk mencapai hal tersebut Indonesia memerlukan pertumbuhan ekonomi paling sedikit $7 \%$ per tahun dimana untuk saat ini baru terealisasi sebesar 5\% pertahun [1]. Indonesia merupakan negara yang $60 \%$ produk domestik brutonya ditopang oleh produk-produk dari Usaha Mikro Kecil Menengah (UMKM) [2]. Potensi UMKM sangat besar untuk kemajuan perekonomian Indonesia. Salah satu UMKM di Indonesia yang memiliki potensial besar adalah UMKM kota Palembang. Kota Palembang mempunyai banyak UMKM yang memiliki beragam produk seperti pakaian, makanan, kerajinan tangan, souvenir dan sebagainya. Produk-produk tersebut memiliki daya saing yang tinggi dan selain menjadi buah tangan bagi wisatawan, produk-produk tersebut juga menjadi konsumsi bagi masyarakat lokal sehingga pengaruh dari konsumsi produk lokal bagi masyarakat lokal tentu saja akan berdampak pada perekonomian lokal [3].

Salah satu cara agar bisa meningkatkan produktivitas UMKM Kota Palembang adalah dengan memanfaatkan teknologi informasi. Teknologi informasi seperti media sosial, sistem penjualan, pembelian, manajemen stok, electronic marketplace dan sebagainya dapat membantu UMKM dalam mengelola dan menjalankan proses bisnisnya. Meningkatkan keterlibatan UMKM dengan teknologi informasi dapat meningkatkan pertumbuhan ekonomi Indonesia sebesar $2 \%$ pertahun. Hal ini merupakan salah satu solusi untuk membantu Indonesia memenuhi target pertumbuhan untuk menjadi negara berpenghasilan menengah pada tahun 2025 yang sebesar 7\% [1].

Penelitian terdahulu yang dilakukan oleh Eko Kus Prasetyo dan Rudy Hartanto [2] mengemukakan bahwa e-marketplace menjadi populer untuk digunakan dikarenakan adanya pengaruh kompetisi ekonomi secara global, yang menyebabkan tuntutan distribusi informasi secara cepat, konsumen yang makin terdidik, inovasi yang cepat dan meningkatnya kompleksitas produk. Dengan pemanfaatan $e$ marketplace, transaksi lintas negara dapat terealisasi serta memungkinkan untuk menciptakan pangsa pasar baru. Untuk membuat sebuah e-marketplace yang baik dibutuhkan sebuah metode atau kerangka acuan yang baik. Enterprise Architecture Planning $(E A P)$ adalah suatu metode atau kerangka acuan yang digunakan untuk membangun suatu arsitektur informasi yang meliputi arsitektur data, arsitektur aplikasi dan juga arsitektur teknologi serta perencanaan implementasi dari 
arsitektur yang telah dibangun tersebut untuk mendukung aktivitas bisnis demi pencapaian misi suatu organisasi dengan berorientasi pada kebutuhan bisnis.

\section{Metode Penelitian}

Penelitian ini menggunakan metode penelitan dan pengembangan atau Research and Development $(R \& D)$. Research and Development adalah kajian yang sistematis tentang bagaimana membuat rancangan suatu produk, mengembangkan/ memproduksi rancangan tersebut, dan mengevaluasi kinerja produk tersebut, dengan tujuan dapat diperoleh data yang empiris yang dapat digunakan sebagai dasar untuk membuat produk, alat-alat dan model yang dapat digunakan dalam pembelajaran dan non pembelajaran [11].

Tahapan dalam penelitian ini dibuat mengacu kepada metodologi dari Enterprise Architecture Planning (EAP). Pengumpulan data dilakukan dengan mengumpulkan dan mempelajari literatur yang berkaitan dengan Usaha Mikro Kecil Menengah (UMKM), emarketplace dan EAP. Sumber literatur berupa buku teks, paper, jurnal, karya ilmiah dan situssitus penunjang lainnya. Data juga didapatkan dengan melakukan wawancara dan observasi terhadap pelaku UMKM Kota Palembang. Jenis wawancara yang digunakan adalah wawancara tak berstruktur. Wawancara tidak terstruktur adalah wawancara yang bebas dimana peneliti tidak menggunakan pedoman wawancara yang telah tersusun secara sistematis dan lengkap untuk pengumpulan datanya. Pedoman wawancara yang digunakan hanya berupa garisgaris besar permasalahan yang akan ditanyakan [12]. Adapun pelaku UMKM yang menjadi informan berjumlah 10 UMKM dengan rincian 4 UMKM di bidang kuliner, 3 UMKM di bidang pakaian dan 3 UMKM di bidang souvenir, kerajinan dan lainnya. Tahap pertama adalah inisialisasi perencanaan. Tahap ini dilakukan agar proyek dapat diproses secara cepat dalam arahan yang benar sejak awal. Pada tahap ini dilakukan pendefinisian terhadap ruang lingkup dan sasaran pengerjaan EAP. Tahapan kedua adalah pemodelan bisnis dimana tahap ini dilakukan untuk mendefinisikan struktur dari model bisnis dan mengidentifikasi serta mendefiniskan fungsi bisnis. Tahapan ketiga adalah sistem dan teknologi saat ini. Tahap ini dilakukan untuk mengidentifikasi dan mendefinisikan sistem dan teknologi apa saja yang sedang digunakan untuk mendukung bisnis. Tahapan keempat adalah arsitektur data. Tahap ini dilakukan untuk mengidentifikasi dan mendefinisikan entitas data yang diperlukan bagi enterprise guna mendukung fungsi bisnis. Tahapan kelima adalah arsitektur aplikasi. Tahap ini dilakukan untuk mengidentifikasi dan mendefinisikan aplikasi-aplikasi yang dibutuhkan dalam pengelolaan data dan mendukung fungsi bisnis enterprise. Tahapan keenam adalah arsitektur teknologi. Tahap ini dilakukan untuk mengidentifikasi dan mendefinisikan prinsip teknologi yang dibutuhkan dalam enterprise untuk mengelola data agar fungsi bisnis dapat berjalan dengan baik. Tahapan ketujuh adalah rencana implementasi. Pada tahap ini akan disusun suatu rekomendasi untuk rencana implementasi yang berdasarkan pada arsitektur yang telah dibuat.

\section{Hasil dan Pembahasan}

Ruang lingkup dan sasaran pengerjaan Enterprise Architecture Planning (EAP) pada penelitian ini adalah proses bisnis dari dari Usaha Mikro Kecil dan Menengah (UMKM) kota Palembang. Berdasarkan hasil wawancara, proses bisnis pada UMKM di Kota Palembang secara keseluruhan hampir sama. Yang membedakan hanya 5 dari 10 UMKM harus melakukan proses produksi terlebih dahulu untuk menghasilkan suatu produk yang siap jual sedangkan yang sebagian lainnya langsung bisa menjual produk dagangannya tanpa harus melalui proses produksi. Secara keseluruhan aktifitas-aktifitas utama UMKM yaitu pembelian barang/bahan, produksi barang, pemasaran dan penjualan barang dan layanan purna jual. Adapun aktifitas-aktifitas pendukung terdiri dari infrastruktur perusahaan yang berupa target penjualan, standar operasional prosedur dan sebagainya, manajemen sumber daya manusia, pengembangan teknologi dan pengadaan. Proses bisnis UMKM Kota Palembang digambarkan dengan model value chain seperti pada Gambar berikut.

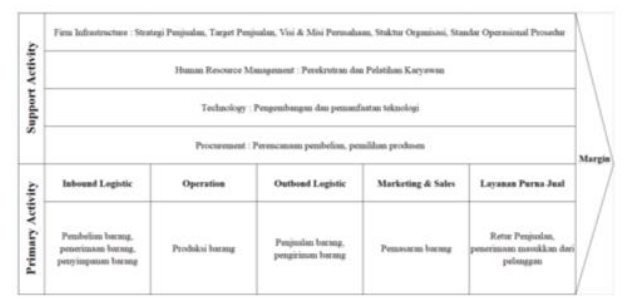

Gambar 1. Value Chain UMKM Kota Palembang 
Proses pembelian barang pada UMKM Kota Palembang masih didominasi dengan sistem konvensional, yaitu proses pemesanan atau pembelian dilakukan dengan membeli barang langsung ke supplier baik dengan datang langsung ke lokasi supplier atau melakukan pemesanan melalui telepon dan media sosial kemudian barang dikirim melalui kurir. Setelah barang atau bahan sampai ke UMKM, pembelian barang tersebut dicatat sesuai dengan nota/faktur pembelian yang diterima oleh UMKM. Sebanyak 6 UMKM melakukan pencatatan pembelian barang dengan menggunakan sistem khusus sedangkan 4 lainnya masih mencatat secara manual di buku catatan atau menggunakan aplikasi perkantoran. Setelah dilakukan pencatatan, barang disimpan di Gudang UMKM untuk kemudian akan dilakukan proses produksi atau langsung dijual. Adapun UMKM yang melakukan pencatatan pembelian dengan menggunakan sistem khusus namun barang yang dibeli merupakan barang/bahan mentah yang belum siap jual, maka barang tersebut tidak dicatat pada sistem. Hal ini dikarenakan sistem yang digunakan tidak mendukung adanya proses produksi yang bisa merubah stok barang/bahan mentah menjadi stok barang yang sudah jadi sehingga barang baru akan dicatat ke dalam stok setelah menjadi barang jadi yang siap jual.

Produksi barang dilakukan oleh 5 dari 10 UMKM. 3 di antaranya belum memanfaatkan mesin dalam melakukan proses produksinya. sedangkan 2 lainnya sudah menggunakan mesin atau alat khusus. Proses produksi barang dilakukan sesuai dengan kebutuhan, ketentuan dan standar operasional prosedur yang telah ditetapkan oleh UMKM. Dalam proses pencatatan, UMKM belum memiliki suatu sistem khusus yang digunakan untuk mencatat proses produksi tersebut, akan tetapi bagi UMKM yang sudah menggunakan sistem khusus untuk melakukan pencatatan pembelian, hasil produksi akan dicatat dengan sistem terebut dan dianggap sebagai pembelian dengan harga beli yang sebelumnya telah dihitung manual.

Dalam proses pemasaran, setiap UMKM sudah menggunakan media sosial sebagai pemasarannya baik berupa Whatsapp, Facebook, Instagram dan sebagainya. Pemasaran melalui media sosial menjadi andalan UMKM karena kemudahan penggunaannya dan biaya yang murah. Adapun penggunaan sistem pemasaran khusus seperti e- marketplace sudah dilakukan oleh 3 dari 10 UMKM. Proses pemasaran dengan media sosial dilakukan dengan cara mengirimkan pesan berupa iklan yang berisi produk-produk yang dijual berserta harganya ke berbagai media sosial. Proses pemasaran pada e-marketplace dilakukan dengan cara melakukan upload terhadap data produk-produk yang dijual ke emarketplace. Jika ada produk yang terjual, UMKM akan menerbitkan suatu bukti penjualan. Sebanyak 4 UMKM masih melakukan pencatatan dan penerbitan bukti penjualan secara manual sedangkan yang lainnya sudah menggunakan sistem khusus. Setelah bukti penjualan terbit, produk yang terjual tersebut akan didistribusikan langsung ke konsumen baik dengan mengantarkannya langsung maupun dengan mengirim melalui kurir jika terdapat jarak yang jauh antara UMKM dengan konsumen.

Layanan purna jual yang terdapat pada UMKM merupakan layanan seperti retur penjualan dan penerimaan masukkan dari konsumen baik berupa komplain maupun saran yang akan ditanggapi langsung oleh UMKM. Retur penjualan akan dilakukan jika terdapat kerusakan pada barang yang baru dibeli oleh konsumen setelah sebelumnya diperiksa terlebih dahulu oleh UMKM. Retur penjualan ini bisa berupa pengembalian uang atau penggantian produk sesuai dengan kesepakatan yang terjadi. Pada proses pencatatan retur penjualan, 6 UMKM sudah menggunakan sistem khusus sedangkan 4 lainnya masih menggunakan cara manual. Untuk menerima masukkan dari konsumen, UMKM memanfaatkan layanan telepon, sms dan media sosial. Tidak ada sistem khusus yang digunakan

Untuk meningkatkan produktifitas UMKM, perlu adanya optimalisasi terhadap proses bisnis UMKM. Cara untuk mengoptimalkannya adalah dengan menciptakan hubungan internal yang kuat antara aktifitas utama dengan aktifitas pendukung. Hubungan internal dapat memengaruhi keunggulan kompetitif dalam dua cara yaitu optimisasi dan koordinasi. Optimalisasi dapat didefinisikan sebagai tindakan, proses, atau pendekatan untuk membuat sesuatu (desain, sistem, atau keputusan) selengkap mungkin, fungsional, atau seefektif (seefisien strategi) mungkin [13]. Dengan memperkuat hubungan antara aktifitas utama dengan aktifitas pendukung seperti infrastruktur perusahaan yang berupa target 
penjualan, standar operasional prosedur, strategi, manajemen sumber daya, pengembangan teknologi dan pengadaan akan membuat tiap-tiap proses bisnis menjadi lebih efisien dan tepat sasaran. Adapun bentuk dari hubungan internal antar tiap aktifitas tersebut adalah : Aktifitas pembelian harus dilakukan dengan mengacu kepada target penjualan untuk menetapkan jumlah barang yang harus dibeli dan berkoordinasi dengan bagian pengadaan yang menentukan produsen barang dengan kualitas barang dan harga yang terbaik. Aktifitas produksi juga dilakukan dengan mengacu kepada target penjualan dan standar operasional prosedur yang telah ditetapkan oleh UMKM untuk menjamin agar jumlah produksi tepat sasaran dan memiliki kualitas yang baik. Aktifitas pemasaran dan penjualan dilaksanakan dengan menjadikan target penjualan sebagai sasaran sehingga bagian pemasaran akan mengetahui langkah-langkah apa saja yang perlu dilakukan agar target penjualan tersebut bisa terpenuhi. Aktifitas layanan purna jual akan memberikan masukkan terhadap standar operasional prosedur dan bagian manajemen sumber daya manusia untuk berkembang lebih baik. Manajemen sumber daya manusia akan menentukan dan mencari pekerja yang diperlukan untuk tiap-tiap aktifitas. Manajemen sumber daya manusia juga memberikan pelatihan kepada pekerja agar kinerja aktifitas bisnis bisa maksimal.

Peran pengembangan teknologi sebagai aktifitas pendukung juga sangat diperlukan untuk mendukung seluruh proses bisnis yang ada. Terutama dengan pemanfaaatan teknologi informasi atau sistem informasi. Sistem informasi merupakan salah satu faktor yang dapat mendukung kemajuan suatu perusahaan untuk dapat bersaing dalam bisnis. Hal ini dikarenakan dukungan sistem informasi atau teknologi informasi dapat meningkatkan efektifitas dan efisiensi kinerja operasionalnya [14]. Organisasi dapat meningkatkan kinerja lingkungan melalui otomatisasi, transformasi dan menginformasikan teknologi informasi termasuk sistem informasi dalam proses bisnis. Dengan demikian, peningkatan yang efektif dari kinerja lingkungan mereka memiliki dampak signifikan pada organisasi untuk meningkatkan profitabilitas organisasi, memberikan peluang bisnis kepada organisasi, meningkatkan posisi kompetitif organisasi di pasar, dan memenuhi peraturan lingkungan pemerintah dan standar internasional bisnis
[15]. Dengan pemanfaatan suatu teknologi informasi khusus, semua proses bisinis dari pembelian, produksi, pemasaran, penjualan dan layanan purna jual akan menjadi lebih efisien dan maksimal. Teknologi informasi akan mempercepat kegiatan proses bisnis, mengurangi biaya akan kebutuhan pekerja yang lebih banyak serta mengurangi resiko human error sehingga biaya operasional dapat ditekan. Dengan teknologi informasi khususnya emarketplace pasar UMKM akan lebih luas sehingga penjualan akan meningkat. Dengan mengoptimalkan hubungan-hubungan antara aktifitas tersebut maka penjualan bisa ditingkatkan dan biaya bisa ditekan sehingga laba dan pertumbuhan UMKM akan meningkat. Oleh karena itu e-marketplace yang dirancang harus bisa mendukung semua proses bisnis terebut sebagai bentuk penguatan hubungan antara aktifitas pengembangan teknologi dengan aktifitas-aktifitas lainnya untuk mencapai margin atau keuntungan yang lebih baik.

Proses penetapan arsitektur data pada EAP menghasilkan sebanyak 6 buah entitas bisnis yang terdiri dari entitas pembelian barang, penyimpanan barang, produksi barang, pemasaran dan penjualan secara online, penjualan secara offline dan layanan purna jual serta 42 buah entitas data.

Penetapan arsitektur aplikasi menghasilkan 6 kandidat aplikasi dan 50 modul yang terdiri dari aplikasi master data, aplikasi pembelian, aplikasi produksi, aplikasi penjualan, aplikasi pemasaran dan aplikasi purna jual. Aplikasi master data mendukung proses penetapan data barang, supplier, pengguna, pelanggan, resep produksi, bank dan kupon. Aplikasi pembelian barang mendukung proses pencatatan data pembelian barang, stok barang masuk, hutang, pelunasan hutang serta pelaporan hasil pembelian, hutang dan pembayaran hutang. Aplikasi produksi mendukung proses pencatatan data produksi, stok hasil produksi serta pelaporan hasil produksi. Aplikasi penjualan mendukung proses pencatatan penjualan barang, stok penjualan, piutang dan pelunasan piutang serta pelaporan penjualan barang, piutang dan pembayaran piutang. Aplikasi pemasaran mendukung penetapan barang yang akan dipasarkan dan pencatatan stok penjualan serta pelaporan hasil pemasaran. Aplikasi purna jual mendukung proses pelaporan masukkan dari pelanggan, pencatatan retur penjualan serta 
pelaporannya. Kandidat aplikasi, 50 modul dan 42 buah entitas data tersebut kemudian dihubungkan sehingga menjadi matriks relasi entitas data terhadap aplikasi seperti pada Gambar 4.

Penetapan arsitektur teknologi menghasilkan platform serta prinsip-prinsip teknologi yang dijadikan sebagai acuan untuk penerapan e-marketplace. Arsitektur teknologi yang dihasilkan bersifat konseptual sehingga bukan merupakan analisis kebutuhan umum dan perlu ditinjau ulang saat melakukan implementasi [16]. E-marketplace harus bisa diakses pengguna baik melalui desktop maupun mobile dengan diperantarai oleh web browser. Web browser lalu menampilkan menu-menu aplikasi sesuai dengan akses yang telah ditentukan. Masing-masing menu aplikasi memiliki fungsi untuk melakukan proses manajemen data baik berupa menambah, mengubah, menghapus dan menampilkan laporan yang kemudian proses tersebut mengarah langsung ke database.

Urutan pengembangan aplikasi bisa ditetapkan dengan mengacu kepada matrik relasi entitas data terhadap aplikasi. Aplikasi yang melakukan create data harus dibuat terlebih dahulu sebelum aplikasi yang melakukan read dan update data.

\section{Kesimpulan}

Penelitian ini menghasilkan model proses bisnis UMKM Kota Palembang baik secara internal maupun eksternal yang digambarkan dengan model chain value yang selanjutnya ditemukan cara untuk meningkatkan produktivitas UMKM Kota Palembang. Penelitian ini juga menghasilkan suatu cetak biru yang meliputi arsitektur data, arsitektur aplikasi, arsitektur teknologi serta perencanaan implementasinya.

Adapun pengembangan aplikasi berdasarkan Enterprise Architecture Planning ini sangat memerlukan dukungan dari semua pihak UMKM Kota Palembang dan juga blueprint e-marketplace yang sudah dihasilkan dari penelitian ini harus terus dilakukan dan dievaluasi agar blueprint yang dihasilkan bisa selalu mengikuti perkembangan zaman.

\section{Daftar Pustaka}

[1] Deloitte, "SMEs Powering Indonesia's success: The Connected Archipelago's Growth Engine," Deloitte Access Econ., pp. 1-56, 2015.

[2] E. K. Prasetyo and R. Hartanto, "Perancangan Website Public EMarketplace Produk Usaha Mikro Kecil dan Menengah ( UMKM ) di Kabupaten Temanggung," Semin. Nas. Ilmu Komput., no. Snik, pp. 238-246, 2016.

[3] A. Delmayuni, "Strategi pengembangan usaha mikro kecil menengah pangan berdaya saing di kota palembang asri delmayuni," 2017.

[4] A. H. Mirza and A. Putra, "Rancang Bangun Model Perangkat Lunak Informasi Ukm Kota Palembang," vol. 8, no. 2, pp. 611-618, 2017.

[5] Republik Indonesia, "UNDANGUNDANG REPUBLIK INDONESIA NOMOR 20 TAHUN 2008 TENTANG USAHA MIKRO, KECIL, DAN MENENGAH DENGAN," UU No. 20 Tahun 2008, no. 1, pp. 1-31, 2008.

[6] K. K. dan UKM, "PERKEMBANGAN DATA USAHA MIKRO, KECIL, MENENGAH (UMKM) DAN USAHA BESAR (UB) TAHUN 2016 - 2017 NO," 2018.

[7] A. S. Research, "Perilaku dan Preferensi KonsumenMillennial Indonesia terhadap Aplikasi E-Commerce 2019," 2019.

[8] G. Jane, A. Santoso, and T. A. Napitupulu, "Factors Affecting Seller Loyalty in Business E- Marketplace: a Case of Indonesia," vol. 96, no. 1, pp. 162-171, 2018.

[9] S. Spewak, "Enterprise Architecture Planning," vol. VIII, no. 1, pp. 47-59, 1993.

[10] K. Budiman, T. Prahasto, and A. Kusumawardhani, "Enterprise Architecture Planning in developing A planning Information System: a Case Study of Semarang State University," vol. 11002, pp. 1-9, 2018.

[11] R. C. Richey and K. D James, Design and Development Research. 2009.

[12] Sugiyono, Metode Penelitian \& Pengembangan (Research and Development). 2017.

[13] P. C. Ensign, "Value Chain Analysis and Competitive Advantage," J. Gen. Manag., vol. 27, no. 1, pp. 18-42, 2017. 
[14] D. Antoni, M. Akbar, and Janurita, "Portfolio Aplikasi Untuk Industri Kelapa Sawit Di Kabupaten Musi Banyuasin," Simetris J. Tek. Mesin, Elektro dan Ilmu Komput., vol. 8, no. 2, p. 693, 2017.

[15] D. Antoni, "Critical Factors of Information Technology Infrastructure Quality for Enhancing Environmental Competencies of the ...," J. Ilm. Matrik, pp. 133-150, 2015.

[16] D. M. Khairina, Mustafid, and B. Noranita, "Enterprise Architecture Planning Untuk Pengembangan Sistem Informasi Perguruan Tinggi," J. Sist. Inf. Bisnis, vol. 03, pp. 117-123, 2012. 